\title{
Bacterial Profile and ESBL Screening of Urinary Tract Infection Among Asymptomatic and Symptomatic Pregnant Women Attending Antenatal Care of Northeastern Ethiopia Region [Corrigendum]
}

\section{Belete MA. Infect Drug Resist. 2020;13:2579-2592.}

The author has advised the affiliation list on page 2579 is incorrect. The correct author list and affiliations are as follows.

Melaku Ashagrie Belete ${ }^{1,2}$

Dawit Gebreegziabiher ${ }^{2}$

Letemichael Negash ${ }^{2}$

Tadele Araya ${ }^{2}$

Muthupandian Saravanan ${ }^{2}$

'Department of Medical Laboratory Science, College of Medicine and Health Sciences, Wollo University, Dessie, Ethiopia; ${ }^{2}$ Department of Medical Microbiology and Immunology, Division of Biomedical Sciences, College of Health Sciences, Mekelle University, Mekelle, Ethiopia

The correspondence section on page 2579 is also incorrect and should be as follows.
Correspondence: Melaku Ashagrie Belete

Department of Medical Laboratory Science, College of Medicine and Health Sciences, Wollo University, Dessie 1145, Ethiopia

Tel +251913867849

Fax +251333115250

Email melakuashagrie@gmail.com

Muthupandian Saravanan

Department of Medical Microbiology and Immunology, Division of Biomedical Sciences, College of Health Science, Mekelle University, Mekelle 1871, Ethiopia

Tel +251344416690

Fax +251344416681

Email saravanan.muthupandian@mu.edu.et

The authors apologize for these errors.

\section{Publish your work in this journal}

Infection and Drug Resistance is an international, peer-reviewed openaccess journal that focuses on the optimal treatment of infection (bacterial, fungal and viral) and the development and institution of preventive strategies to minimize the development and spread of resistance. The journal is specifically concerned with the epidemiology of antibiotic resistance and the mechanisms of resistance development and diffusion in both hospitals and the community. The manuscript management system is completely online and includes a very quick and fair peerreview system, which is all easy to use. Visit http://www.dovepress.com/ testimonials.php to read real quotes from published authors. 